\title{
Planning for climate action in British Columbia, Canada: Putting agricultural greenhouse gas mitigation on local government agendas
}

Tara L. Moreau, ${ }^{\mathrm{a}, *}$ Jennie Moore, ${ }^{\mathrm{b}}$ and Kent Mullinix ${ }^{\mathrm{c}}$

Submitted 18 April 2011 / Revised 4 July 2011 and 1 August 2011 / Accepted 2 September 2011 / Published online 20 March 2012

Citation: Moreau, T. L., Moore, J., \& Mullinix, K. (2012). Planning for climate action in British Columbia, Canada: Putting

agricultural greenhouse gas mitigation on local government agendas. Journal of Agriculture, Food Systems, and Community

Development, 2(2), 247-259. http://dx.doi.org/10.5304/jafscd.2012.022.008

Copyright (C 2012 by New Leaf Associates, Inc.

\begin{abstract}
Significant greenhouse gas (GHG) reductions from all sectors of human enterprise are necessary to avoid further effects and reduce the current effects of climate change. Agriculture and the global food system are estimated to contribute to one-third of all anthropogenic GHGs. In British Columbia, Canada, mandated GHG reduction targets and voluntary climate action programs are challenging local governments to include emission reduction targets, policies, and actions within official planning documents. At this early stage of GHG
\end{abstract}

\footnotetext{
a,* Corresponding author: Tara Moreau, Pacific Institute for Climate Solutions, University of British Columbia, Canada, 2060 Pine Street, Vancouver, British Columbia V6J 4P8 Canada; +1-604-783-8571; taramoreau@gmail.com

b Pacific Institute for Climate Solutions, School of Community and Regional Planning, University of British Columbia; jennielynnmoore@hotmail.com

${ }^{\mathrm{c}}$ Institute for Sustainable Horticulture, Kwantlen Polytechnic University, Surrey, British Columbia, Canada; kent.mullinix@kwantlen.ca
}

Note: Funding for this project was provided by the Pacific Institute for Climate Solutions. reductions, local government attention does not yet include agriculture but is directed toward the transportation, buildings, and waste management sectors. Given agriculture's contribution to GHG emissions and local government's engagement with GHG mitigation and food system planning, it seems reasonable to anticipate that over time, local governments should and will engage increasingly in reducing GHGs from agriculture. With the goal of advancing agriculture GHG mitigation by local governments, this paper reviews the jurisdictional powers governing agriculture and climate change within British Columbia. It examines how local governments can support mitigation within the sector through their roles in planning, policy, programming, and public engagement, and identifies potential research agenda items.

\section{Keywords}

agriculture, climate change, greenhouse gas emissions (GHGs), GHG inventory, GHG mitigation, local government, planning, policy

\section{Introduction}

Climate change poses a significant challenge to humanity and will require definitive action by 
society for profound, transformative change. Significant reductions of greenhouse (GHG) emissions in every sector, including agriculture and the agri-food system as a whole, are necessary and will require strategic coordination and planning. Mitigation and adaptation are the two main climate change response options outlined by the United Nations Framework Convention on Climate Change (UNFCCC). Mitigation of climate change involves reducing GHG emissions entering the atmosphere and removing atmospheric GHGs through sinks (such as carbon sequestration). Adaptation refers to building resistance (the ability to withstand the impact of a disturbance) and resilience (the ability to recover from disturbance) within agro-ecosystems, communities, and governance frameworks, to prepare for climatic change and its impacts. Although adaptation within the agriculture sector is vital, the focus of this paper is on GHG mitigation.

Greenhouse gas emissions from the global food system are estimated to contribute to one-third of all anthropogenic (human generated) emissions (Intergovernmental Panel on Climate Change (IPCC), 2007; Scialabba \& Muller-Lindenlauf, 2010). While GHG emissions reductions are necessary in all stages of the food system (agriculture, processing, packaging, transportation, retailing, catering and consumption, home preparation, and waste management), particular attention to agriculture is necessary in order to ensure food security, economic vitality, and sustainable communities congruently. Agriculture (the cultivation and production of food, fuel, and fiber) contributes between $10 \%$ and $25 \%$ of annual GHG emissions, mainly through methane, nitrous oxide, and carbon dioxide emissions from land-use changes, agricultural land management, and farming practices (Scialabba \& Muller-Lindenlauf, 2010; Smith et al., 2008).

In British Columbia (B.C.), Canada, provincial climate policies mandate that local governments achieve significant GHG reduction targets within their operations. The targets seek to reduce GHG emissions to $33 \%$ below 2007 levels by 2020 and to $80 \%$ below 2007 levels by 2050 . As part of these regulations, local governments are required to include GHG reduction targets, policies, and actions in their two main planning frameworks: Regional Growth Strategies (RGSs) (in effect since 31 May 2011) and Official Community Plans (OCPs) (in effect since 31 May 2010). At this early stage of being required to consider GHG reductions in the regional and community plans, local government's attention to emissions reductions is not yet directed towards agriculture, but is focused on sectors where the greatest reductions are thought to exist, namely buildings, transportation, and waste, which are under their operational authorities.

Historically, local governments in B.C. have been instrumental in implementing sustainable practices within local contexts (Nowlan, Rolfe, \& Grant, 2001). With this track record, it is reasonable to anticipate that over time, local initiatives will be designed to meet climate change mitigation and adaptation challenges within the local agricultural sector. For example, there is a growing engagement by local governments in regional food system planning, which has been supported by a partnership involving federal, provincial, and local governments (City of Vancouver, 2011; Metro Vancouver, 2011). This partnership is being extended to cover climate change themes (British Columbia Healthy Communities, 2011). With these types of initiatives, along with new planning legislation, and as more information is available on ways to reduce agriculture GHG emissions, local governments will be in the position to play a role in reducing agriculture and food production emissions.

Although the points noted above hold promise for local government involvement in GHG mitigation of agriculture, they also highlight the diversity of interests and their associated complexity. It is important to step back and begin to outline a stepby-step strategy for defining and achieving effective results. One of the first steps in mitigation planning commonly recommended is to identify and understand all existing policies and programs that influence a sector's ability to implement change and take action to reduce emissions (British Columbia Ministry of Community, Sport and 
Cultural Development, 2010). For agriculture, this is a complicated task that requires assessing the multilevel jurisdictional authority of national, provincial, and local levels of government, as well as the laws, policies, and programs administered by each.

Although local governments in B.C. are increasingly engaged in both GHG emissions reduction planning and food system planning, the two planning strategies remain disconnected, and as a result, local-level GHG mitigation within the agriculture sector is not being properly addressed. With the goal of raising awareness of the necessity for agriculture mitigation planning by local governments and to increase knowledge of those engaged in local/regional food system planning, we provide an overview of the jurisdictional powers governing agriculture and climate change within British Columbia and provide detailed attention to the role that local governments can have in creating local initiatives designed to mitigate GHGs within the province's agricultural sector.

\section{Jurisdictional Powers Governing Agriculture and Climate Change}

Addressing mitigation within the agriculture sector and creating effective strategies for climate action requires some knowledge about the jurisdictional powers of different levels of government (national, provincial, and local). Canada is a federation of provinces where the orders of government have distinct, but in some cases overlapping, jurisdictions (Curran, 2009). Both federal Parliament and provincial legislatures have the constitutional authority to make laws (Nowlan et al., 2001), but local governments (both regional and municipal) do not have standalone legal authority. Their powers are delegated to them through provincial regulations, such as the Local Government Act. Even if they have power to make many decisions that affect agriculture, this may be limited by their legislation or other federal and provincial enactments. Furthermore, local governments have discretionary authority with respect to the use of their powers. They can also choose whether to participate in federal and provincial initiatives. Having an understanding of the interplay among these considerations is imperative to designing an effective, locally based GHG emissions strategy and implementation programs for the agriculture and agri-food sector.

\section{Federal and Provincial Agriculture Policy}

Canada's constitutional arrangement puts jurisdiction and legislative authority over agriculture in the hands of the federal and provincial governments, both of which voice authority in realms of international trade, marketing, interprovincial coordination, and subsidy regulation, among others (Found, 1996). The five main federal governing agencies involved with agriculture in Canada include: Agriculture and Agri-Food Canada (AAFC), the Canadian Food Inspection Agency (CFIA), the Department of Fisheries and Oceans (DFO), Environment Canada, and Health Canada (Department of Justice, 2011). Agencies are responsible for particular services and for administering and enforcing particular acts and regulations (see table 1) (Fuller \& Buckingham, 1999). At the federal level, we identified a total of 33 enactments that potentially affect agriculture and food production.

Within B.C., we identified 10 key provincial acts affecting agriculture (see table 1) (B.C. Ministry of Agriculture, 2011; Curran, 2009). The Agricultural Land Reserve Act (ALC Act), initially enacted in 1973 with major revisions in 2002, applies to private and provincial land within the Agricultural Land Reserve (ALR) and is the primary authority used to protect B.C. farmland from urban sprawl, as well as purportedly to promote agriculture's viability. This act is critical to land use policies and takes precedence over most other legislation. It effectively links provincial interests to local government land use planning and bylaw functions. Furthermore, it restricts the placement of fill on, or removal of soil from, land in the ALR. The Assessment Act establishes provincial authority and responsibility for property value assessment. Local governments set tax rates that apply to these assessed values. The Environmental Management Act governs multiple practices relating to farm operations, including management of agricultural waste (e.g., pesticide and fertilizer waste, compost, 
Table 1. Federal, Provincial, and Local Government Policies, Policy Tools and Programs Influencing Agriculture and Climate Change in British Columbia, Canada

\begin{tabular}{|c|c|c|c|c|c|}
\hline $\begin{array}{l}\text { Governance } \\
\text { Level }\end{array}$ & $\begin{array}{l}\text { Agriculture Acts and Regulations } \\
\text { (Governing Agency) }\end{array}$ & Agriculture Policy Tools & $\begin{array}{l}\text { Climate Change Acts } \\
\text { and Regulations }\end{array}$ & $\begin{array}{l}\text { Climate Change } \\
\text { Policy Tools }\end{array}$ & $\begin{array}{l}\text { Programs Addressing } \\
\text { Both Agriculture and } \\
\text { Climate Change }\end{array}$ \\
\hline $\begin{array}{l}\text { Federal: } \\
\text { Canada }\end{array}$ & $\begin{array}{l}\text { - } \text { Agriculture and Agri-Food Administrative } \\
\text { - } \text { Animal Pedigree Act (AAFC) } \\
\text { - } \text { Canada Agricultural Products Act (CFIA) } \\
\text { - Canada Grain Act (AAFC) } \\
\text { - Canada Water Act (Environment Canada) } \\
\text { - Canadian Agricultural Loans Act (AAFC) } \\
\text { - Canadian Dairy Commission Act (AAFC) } \\
\text { - Canadian Environmental Protection Act, } \\
\text { - } 1999 \text { (Environment Canada) } \\
\text { - Canadian Food Inspection Agency Act (CFIA) } \\
\text { - Canadian Wheat Board Act (AAFC) } \\
\text { - } \text { Departitution Act, 1867 } \\
\text { - } \text { (AAFC) } \\
\text { - } \text { (Envartment of Agriculture and Agri-Food Act } \\
\text { - Environment Environment Act } \\
\text { Canada) } \\
\text { - Experimental Farm Stations Act (AAFC) } \\
\text { - Farm Credit Canada Act (AAFC) } \\
\text { - Farm Income Protection Act (AAFC) } \\
\text { - Feeds Act (CFIA) } \\
\text { - Fertilizers Act (CFIA) } \\
\text { - Fish Inspection Act (CFIA) } \\
\text { - Food and Drugs Act (CFIA) } \\
\text { - Hazardous Products Act (Health Canada) } \\
\text { - Health of Animals Act (CFIA) } \\
\text { - International River Improvements Act } \\
\text { (Environment Canada) } \\
\text { - Meat Inspection Act (CFIA) } \\
\text { - Pest Control Products Act (Health Canada) } \\
\text { - Pesticide Residue Compensation Act (Health }\end{array}$ & $\begin{array}{l}\text { - Growing Forward } \\
\text { Framework The Way } \\
\text { Forward: Summary of } \\
\text { Agriculture and Agri- } \\
\text { Food Canada's } \\
\text { Science and Innova- } \\
\text { tion Strategic Action } \\
\text { Plan } 2010 \text { (Agricul- } \\
\text { ture and Agri-food } \\
\text { Canada (AAFC), } \\
\text { 2010) }\end{array}$ & $\begin{array}{l}\text { - Budget Implementa- } \\
\text { tion Act, } 2007 \text { (Clean } \\
\text { Air and Climate } \\
\text { Change Trust Fund) } \\
\text { - Canadian Emission } \\
\text { Reductions } \\
\text { Incentives Agency Act } \\
\text { - Canadian Foundation } \\
\text { for Sustainable } \\
\text { Development } \\
\text { Technologies Act } \\
\text { - Kyoto Protocol } \\
\text { Implementation Act }\end{array}$ & $\begin{array}{l}\text { - National Resources } \\
\text { Canada: The Climate } \\
\text { Change Impacts and } \\
\text { Adaptation Division } \\
\text { (ecoAction, 2007) }\end{array}$ & $\begin{array}{l}\text { The eco-Agriculture } \\
\text { Biofuels Capital } \\
\text { Initiative (ecoAction, } \\
\text { 2007) }\end{array}$ \\
\hline
\end{tabular}




\begin{tabular}{|c|c|c|c|c|c|}
\hline $\begin{array}{l}\text { Governance } \\
\text { Level }\end{array}$ & $\begin{array}{c}\text { Agriculture Acts and Regulations } \\
\text { (Governing Agency) }\end{array}$ & Agriculture Policy Tools & $\begin{array}{l}\text { Climate Change Acts } \\
\text { and Regulations }\end{array}$ & $\begin{array}{l}\text { Climate Change } \\
\text { Policy Tools }\end{array}$ & $\begin{array}{l}\text { Programs Addressing } \\
\text { Both Agriculture and } \\
\text { Climate Change }\end{array}$ \\
\hline & $\begin{array}{l}\text { Canada) } \\
\text { - Plant Breeders' Rights Act (CFIA) } \\
\text { - Plant Protection Act (CFIA) } \\
\text { - Prairie Farm Rehabilitation Act (AAFC) } \\
\text { - Seeds Act (CFIA) } \\
\text { - Species at Risk Act (Environment Canada) }\end{array}$ & & & & \\
\hline $\begin{array}{l}\text { Provincial: } \\
\text { British Columbia }\end{array}$ & $\begin{array}{l}\text { - Agriculture Land Commission Act } \\
\text { - Assessment Act } \\
\text { - Environmental Management Act } \\
\text { - Farm Practices Protection (Right to Farm) Act } \\
\text { - Fish Protection Act } \\
\text { - Integrated Pest Management Act } \\
\text { - Land Titles Act } \\
\text { - Local Governments Act } \\
\text { - Natural Products Marketing Act } \\
\text { - Water Act }\end{array}$ & $\begin{array}{l}\text { - The British Columbia } \\
\text { Agriculture Plan: } \\
\text { Growing a Healthy } \\
\text { Future for B.C. Famil- } \\
\text { ies (B.C. Ministry of } \\
\text { Agriculture, 2008a) } \\
\text { - The Environmental } \\
\text { Farm Plan (B.C. } \\
\text { Ministry of } \\
\text { Agriculture, 2011a) } \\
\text { - ALR and Community } \\
\text { Planning Guidelines } \\
\text { (Agricultural Land } \\
\text { Commission (ALC), } \\
\text { 2011) }\end{array}$ & $\begin{array}{l}\text { - } \text { Carbon Tax Act } \\
\text { - Environmental } \\
\text { Management Act } \\
\text { - Greenhouse Gas } \\
\text { Reduction Targets } \\
\text { Act (GGRTA) } \\
\text { - Local Government } \\
\text { Statutes Amendment } \\
\text { Act } \\
\text { - Zero Net } \\
\text { Deforestation Act }\end{array}$ & $\begin{array}{l}\text { - The B.C. Provincial } \\
\text { Climate Action Plan } \\
\text { (B.C. Ministry of } \\
\text { Environment, 2009) } \\
\text { - Preparing for Climate } \\
\text { Change: Securing } \\
\text { B.C.'s Water Future } \\
\text { (Natural Resources } \\
\text { Canada, 2011) }\end{array}$ & $\begin{array}{l}\text { - B.C.'s Agricultural } \\
\text { Sector and the } \\
\text { Greenhouse Gas } \\
\text { Reduction Targets } \\
\text { Act (B.C. Ministry of } \\
\text { Agriculture, 2009) } \\
\text { - B.C. Climate Action } \\
\text { Plan (Climate Action } \\
\text { Initiative, 2010) } \\
\text { - A Crop for the 21st } \\
\text { Century: Carbon } \\
\text { Credits and Agricul- } \\
\text { ture in British Colum- } \\
\text { bia (B.C. Ministry of } \\
\text { Agriculture, 2008b) }\end{array}$ \\
\hline $\begin{array}{l}\text { Local } \\
\text { Government }\end{array}$ & $\begin{array}{l}\text { - Regional Growth Strategies (RGS) } \\
\text { - Official Community Plans (OCP) } \\
\text { - Agricultural Area Plans (AAP) } \\
\text { - Bylaws (zoning and farm) } \\
\text { - Development Permit Areas }\end{array}$ & $\begin{array}{l}\text { - Agricultural Plans for } \\
\text { Local Governments in } \\
\text { British Columbia (B.C. } \\
\text { Ministry of Agricul- } \\
\text { ture, 2011c) } \\
\text { - Metro Vancouver } \\
\text { Regional Food } \\
\text { System Strategy } \\
\text { (Metro Vancouver, } \\
\text { 2011) } \\
\text { - Planning for Agricul- } \\
\text { ture (Smith, 1998) } \\
\text { - Vancouver Food } \\
\text { Charter (City of } \\
\text { Vancouver, 2011) }\end{array}$ & & $\begin{array}{l}\text { - Climate Action } \\
\text { Charter } \\
\text { - Community-Wide } \\
\text { Climate Action Plan- } \\
\text { ning Framework } \\
\text { (British Columbia } \\
\text { Ministry of Commu- } \\
\text { nity, Sport and } \\
\text { Cultural Develop- } \\
\text { ment, 2010) } \\
\text { - Partners for Climate } \\
\text { Protection }\end{array}$ & \\
\hline
\end{tabular}

Note: CFIA = Canadian Food Inspection Agency; AAFC = Agriculture and Agri-Food Canada 
biosolids, etc.), open burning, and application of compost and biosolids to agricultural land. The Farm Practices Protection (Right to Farm) Act applies to farmers operating in the ALR or in areas zoned for or licensed to farming. As long as farmers comply with other legislative acts (the Environmental Management Act, Integrated Pest Management Act, and Public Health Act), the act protects farmers following "normal farm practices" from nuisance claims or complaints about potential disturbances resulting from farm operations. The policies and guidelines of the act help link farm practices with local land use policies, with the goal of balancing farmer rights with those of nearby residents. The Fish Protection Act requires permits for farming or development near streams or open fish-bearing waterways. The Integrated Pest Management Act describes general requirements for pesticide use and sales. The Land Titles Act authorizes local governments to approve or refuse applications for building subdivisions on farmland. The Local Government Act (LGA) delegates provincial power to local governments. Within this act, and through the Farm Practices Protection (Right to Farm) Act and the Agricultural Land Commission Act, provincial responsibility for agriculture is linked to local government bylaws. Under the LGA, local government responsibility for and oversight of agriculture applies to land use, planning, zoning, and building and/or development control. However, care needs to be taken when interpreting these powers as their use is fettered by other provincial legislation, for example the ALC Act. The Natural Products Marketing Act governs the promotion, control, and regulation of natural products within B.C. The Water Act gives the province control over all surface and groundwater.

\section{Federal and Provincial Climate Change Policy}

Canada ratified the United Nations Framework Convention on Climate Change (UNFCCC) in 1992, which requires national governments to gather and share information on GHG emissions, best practices, and national policies. The UNFCCC commits governments to launching national strategies for addressing GHG emissions and climate change adaptation, and requires nations to cooperate in preparing for climate change impacts (UNFCCC, 2011). The Kyoto Protocol, which was adopted by Canada in 1997 and entered into force in 2005 , is an international agreement linked to the UNFCCC that sets binding targets for industrialized countries to reduce GHG emissions by $5 \%$, against 1990 levels, over the years 2008-2012. The main distinction between the convention and the protocol is that the former encouraged industrialized countries to stabilize GHG emissions, while the latter commits them to doing so. In 2011, Canada was the first country to formally withdraw from the Kyoto Accord. The Canadian government said the Kyoto protocol would not work because it did not include the United States and China, the world's two largest emitters. Furthermore, the government said it needed to avoid the $\$ 14$ billion in penalties for not meeting its goals. The Canadian national GHG emissions estimates reported in the 2008 National Inventory Report (NIR) of $734 \mathrm{MtCO}_{2} \mathrm{e}^{1}$ were $33.9 \%$ above Canada's Kyoto Protocol target (563 $\mathrm{MtCO}_{2} \mathrm{e} /$ year for 2008-2012). In 2009, Canada signed the Copenhagen Accord through which Canada is committed to reducing GHG emissions, based on 2005 emissions, by $17 \%$ by 2020 (ecoAction, 2011). This means that by 2020, Canada's total annual emissions must be below 620 $\mathrm{MtCO}_{2}$ e. Unlike the Kyoto Accord, the Copenhagen Accord includes both the United States and China and is not legally binding.

In B.C., the 2007 Greenhouse Gas Reduction Targets Act (GGRTA) and the 2008 Local Government Statutes Amendment Act mandate the province, including its local governments, to reduce GHG emissions to 33\% below 2007 levels by 2020 and to $80 \%$ below 2007 levels by 2050 . The GGRTA made B.C. the first jurisdiction in North America to make a legally binding commitment to achieving carbon-neutral operations. Using 2007 as the baseline year of emissions (68.0

\footnotetext{
${ }^{1} \mathrm{MtCO}_{2} \mathrm{e}$ is the standard measurement of the amount of $\mathrm{CO}_{2}$ emissions that are reduced or secluded from our environment, and stands for metric tonne (ton) carbon dioxide equivalent. A ton of carbon dioxide equals 2204.62 pounds of $\mathrm{CO}_{2}$ (“Common Questions About $\mathrm{MtCO}_{2}$, " 2008).
} 
$\left.\mathrm{MtCO}_{2} \mathrm{e}\right)$, B.C. is mandated to reduce its emission to $45.5 \mathrm{MtCO}_{2} \mathrm{e}$ by 2020 and to $13.6 \mathrm{MtCO}_{2} \mathrm{e}$ by 2050. The GGRTA also commits the provincial government and public-sector organizations (e.g., Crown corporations, health authorities, universities, colleges and school districts) to carbon neutrality, which requires measuring GHG emissions, reducing them where possible, offsetting the remainder, and reporting them (B.C. Ministry of Environment, Climate Action Secretariat, 2009).

\section{The Role of Local Governments in Mitigating GHGs Within Agriculture}

Thought of as the level of government "closet to the people," local governments have historically played a key role in addressing sustainability issues within B.C. because of their role in land use planning, service delivery, policy, and regulation (Nowlan et al., 2001). Local government refers to the council of a municipality or the board of a regional district. The province of British Columbia has 151 municipalities within 27 larger regional districts (Nowlan et al., 2001). Local government attention to agriculture can yield multiple cobenefits that support development of sustainable communities. As Daniel Hernandez, quoted by Benfield, succinctly put it,

Our challenge as planners, developers and policy-makers of the built environment in an era of climate change is to figure out how to strengthen agriculture systems and biodiversity of our farmlands, and connect them to livable cities and their consumers. Our intention should be to support policies that preserve these valuable resources and strengthen their economic viability. (Benfield, 2011)

For local governments in B.C., provincial climate change statutes mandate that local governments include GHG emission reduction targets, policies, and actions in their official planning documents (B.C. Ministry of Environment, 2009). The bulk of local government GHG emissions attention, at present, is directed toward the transportation, buildings, and waste-management sectors where local government is perceived to exercise the most influence and where the greatest potential for significant GHG reductions is thought to reside. Although there are global frameworks that inventory agriculture GHG emissions and agriculture emissions are accounted for in national, provincial, and regional inventories, local-level agriculture emissions are not currently included with local government emissions reporting. Nor does local government engage in agriculture or food system GHG mitigation planning. Reasons why local governments may not engage in agriculture GHG mitigation planning include (1) a perception by local government that they have limited influence over production; (2) agriculture is not currently included in municipal emission inventories (out of sight, out of mind); and (3) the complexity and uncertainty associated with understanding agriculture GHG mitigation make planning in this domain difficult.

Local governments in B.C. are seeking ways to help agriculture within their areas, including planning for local and/or regional agri-food systems (Connell \& Sturgeon, 2011; Smith, 1998). We suggest that mitigating GHGs within agriculture is an important area for local government attention. Thus in the remainder of this paper we review local governments' roles within the context of agriculture GHG mitigation in the areas of (1) planning, (2) policy, (3) program participation, facilitation, and support, and (4) public promotion.

\section{Planning}

Agriculture planning has a long history within British Columbia. In the 1970s and 1980s, planning activities were focused on preserving agricultural land, culminating in the Agricultural Land Commission (ALC) Act and the Agricultural Land Reserve (ALR). In the 1990s, the province's planning focus shifted to improving farming practices. This shift resulted in amendments to the ALC Act and the Local Government Act and in the enactment of the Farm Practices Protection (Right to Farm) Act. In B.C., the three types of planning tools that have the greatest influence on land use and community design for agriculture are Regional Growth Strategies (RGSs), Official Community Plans (OCPs), and Agricultural Area 
Plans (AAPs). RGSs, which should directly reflect provincial planning goals, are developed by regional districts and must be agreed upon by constituent municipalities. The Local Government Act establishes authority for the RGS and states that the purpose of an RGS is to "promote human settlement that is socially, economically and environmentally healthy and makes efficient use of public facilities and services, land and other resources" (British Columbia Laws, 2011). RGSs typically cover a range of issues and set a 20 -year vision for regional growth and development. OCPs, which can be developed by both regional districts for unincorporated areas and municipalities for all or part of their jurisdiction, must be consistent with RGSs. OCPs are based on a 5 -year planning horizon and state the objectives and policies that guide decisions on planning and land use management within the area covered by the plan. On 31 May 2010, legislation was enacted to require OCPs to address GHG reduction. AAPs are developed by local governments in partnership with agricultural advisory committees and other stakeholders in the community and recommend strategies to encourage and enhance agriculture (B.C. Ministry of Agriculture, 2011b). The provincially supported Local Government Agricultural Planning (LGAP) program provides financing to local governments to support AAP development within municipal and regional districts. AAPs provide direct linkages with OCPs, give baseline assessments of the agriculture land base, highlight opportunities and challenges facing local agriculture, support the creation of land use policies and designations, detail planning implementation strategies, and recommend zoning and farming bylaws. In order to become official and obtain the same legal status as an OCP, AAPs must be formally adopted by local governments.

Local governments are increasingly recognizing the importance of regional agri-food systems. In March 2011, Metro Vancouver completed a Regional Food System Strategy and at least six of its member municipalities had completed agricultural area plans and strategies (Metro Vancouver, 2011; B.C. Ministry of Agriculture, 2011c). The city of Surrey's Sustainability Charter is a comprehensive framework for implementing a 50-year vision for a sustainable city (City of Surrey, 2011). The city of Vancouver's Food Charter conveys a vision and key principals for a sustainable food system (City of Vancouver, 2011). However, while local government planning efforts are increasingly recognizing the importance of advancing sustainable food systems, few plans deal directly with climate change, production agriculture, and GHG mitigation in an integrated way. Nevertheless, it seems reasonable to anticipate that over time local governments will increasingly engage in reducing agriculture and food system GHG emissions.

Agricultural planning at the local level is expected to confer numerous benefits, which include reducing urban/rural conflict through stakeholder engagement; improving local farming economic activity; supporting consistency within federal and provincial policies; stimulating new thinking and changing attitudes of stakeholders involved with the planning process; enabling agricultural planning integration into larger community plans; providing support language and knowledge to assist local government in making land use decisions; and creating a methodology for dealing with issues that arise (Connell \& Sturgeon, 2011; Nowlan et al., 2001). All the benefits of agricultural planning highlight the support and demonstrate the need for GHG mitigation planning within the sector at the local and/or regional level.

In B.C., provincial policies mandating municipalities to include GHG reduction targets and actions within their planning frameworks provide impetus for planners to bring forward innovative and effective strategies. The B.C. Climate Action Plan describes GHG reduction strategies for agriculture, while other documents discuss agriculture and carbon offset trading (see table 1) (B.C. Ministry of Agriculture, 2008b). However, there is little information related to how practices to mitigate agricultural GHG emissions can be implemented and incorporated into RGSs, OCPs, or other programs (B.C. Ministry of Environment, 2009). The B.C. Agriculture Climate Change Action Plan developed by agriculture industry uses a number of guiding principles to outline both strategic direction and 
concrete action for mitigation and adaptation by the sector (Climate Action Initiative, 2010).

\section{Policy}

From the legal perspective, mitigating GHG emissions from agriculture is a challenge due to the number of interconnected policies and regulations that directly address or indirectly influence agriculture and climate change actions. Furthermore, a number of nonclimate and nonagriculture policies (e.g., international free trade agreements, trade barriers, energy policies, and environmental policies) also affect emission reductions activity (Smith et al., 2007). Although jurisdiction and legislative authority over Canadian agriculture ultimately resides with federal and provincial governments, local government policies (mainly via bylaws and development permits) can significantly affect agricultural production or climate action at the local level (British Columbia Local Government Department, 2011; Curran, 2009).

Local government bylaws and permits translate the policies and recommended practices within RGSs and OCPs into requirements that can affect agriculture in multiple ways, including parcel size determination, regulation of nonfarm land use, urban agriculture interface planning, rainwater management, direct farm business marketing, agritourism regulations, composting management, agricultural product processing, and accommodation regulations. Subject to approval by the Minister of Agriculture, farming bylaws related to farm operations, buildings, buffers, waste, and environmental practices are also developed and governed by local governments (British Columbia Ministry of Agriculture, 1998).

\section{Program Participation and Support}

Local governments in B.C. participate in two key climate change programs: Partners for Climate Protection (PCP) and the Climate Action Charter. The PCP program calls for participating municipalities to: (1) complete a GHG inventory, (2) set emission reduction targets, (3) develop a plan to reduce those emissions, (4) implement the plan, and (5) monitor and report on the results (Federation of Canadian Municipalities \& ICLEI,
2010). The program is delivered across Canada with 216 municipalities participating, 66 of which are located in B.C. (Federation of Canadian Municipalities, 2011). Current inventory protocols do not account for agriculture emissions. Only emissions from transportation, buildings, and waste-management sectors are measured. The initial rationale for agriculture's omission is that local governments exercise only limited influence in this realm (National Climate Change Secretariat, 1998). However, given the important role that local governments can play in helping citizens and consumers of agricultural products make climate-smart purchasing decisions, and given the role that local governments can play to enable local agriculture, it may be timely to review these original assumptions.

As signatories of the Climate Action Charter, over 178 local governments in B.C. have voluntarily committed to becoming carbon-neutral by 2012 (B.C. Ministry of Community and Rural Development, 2010). The Climate Action Charter requires that local governments measure their organizational emissions, reduce GHG emissions and energy use, and offset remaining operational emissions to achieve a net zero. This program complements the PCP program and follows a similar emission inventory protocol targeting the transportation, buildings, and waste-management sectors.

In addition to participating in programs that address agriculture and climate change, local governments can enable GHG mitigation within agriculture by supporting local programs that assist producers in adopting regionally appropriate mitigation practices. For example, they can provide support for necessary infrastructure or subsidies to increase farmer adoption of otherwise costly practices. Furthermore, local government advocating for including agriculture GHG emissions in Community Energy and Emissions Inventories could provide baseline data that is essential to informing local prioritized reduction strategies.

\section{Public Promotion and Stakeholder Coordination}

Local government engagement with the public, farmers, communities, industry, and the provincial 
and federal government enables it to foster dialogues, partnerships, and capacity-building opportunities necessary for climate change mitigation action within agriculture. For example, hosting public gatherings or events that support low GHG agriculture or building links between urban food activists and commercial producers are other actions that local governments can take toward climate action.

\section{Discussion and Conclusion}

Climate change represents a significant challenge, as it will undoubtedly require profound, transformational change in how we live on Earth and conduct the human enterprise, including food production. Ultimately, local initiatives designed to meet regional mitigation challenges are necessary for the agriculture sector in B.C. as elsewhere. Local governments involvement with sustainability, GHG emissions reductions, and local/regional agri-food systems development in conjunction with their roles in planning, policy, program development, and stakeholder engagement suggest they have an important, even critical, role to play in mitigating GHGs in agriculture. However, they cannot undertake this task alone, because mitigation actions are closely linked to provincial, federal, and international policies and programs. In addition to navigating the complex policy framework that affects agriculture, local governments must accept the challenge of identifying how to mitigate GHGs in agriculture despite the uncertainties associated with the scientific information (see Moreau et al. 2011 in this issue). To advance GHG mitigation planning in British Columbia we suggest the following research agenda items for local governments.

\section{Coordinating and Planning for Systemic Action: Taking} aggressive action toward tackling climate change requires concerted, focused strategic planning involving a multitude of stakeholders. Local government training and experience in community and economic development, design, natural resource stewardship planning, public consultation, and visioning means they are well suited to address strategic planning for climate action within agriculture and food systems. However, it is not likely that many staff have sufficient training in or knowledge of agricultural sciences or agro-ecology. Having staff receive training in both planning and agriculture would greatly enhance the systemic planning that is necessary. Alternatively, active and positive engagement with the agricultural community and regional experts, similar to the approach used to engage any community of interest in local planning processes, provides a start.

Education: Local government-supported partnerships between stakeholders can work to increase awareness and promotion of low GHG agricultural practices by educating and supporting farmers to improve efficiencies and by providing low GHG agriculture information to stakeholders. For example, educational campaigns aimed at encouraging land managers to minimize fertilizers based on the principles of "the right source, the right placement, at the right rate, and at the right time" may improve nitrogen efficiency and reduce costs while also reducing $\mathrm{N}_{2} \mathrm{O}$ emissions and runoff. Furthermore, local government can raise consumer awareness about sustainable diets and encourage consumption behaviors that support low GHG foods (e.g., provide information on the benefits of a diet low in animal protein). University extension personnel, in collaboration with local government, should be called upon to establish low GHG farming demonstrations, disseminate applied research findings, and otherwise provide technical assistance to farmers and planners to implement low GHG farming practices.

Incentives and Investment: Promoting and enabling the transformation to low GHG agriculture production requires incentive and support for farmers and land managers (e.g., financing, public investments, crop insurance, payment for environmental services, carbon offset markets, etc.). Early investment in mitigation and adaptation actions is essential to building long-term resilience of the sector (Meridian Institute, 2011).

Local Government GHG Inventories Need To Account for Agriculture Emissions: Getting production agriculture included in local government inventories is a 
necessary first step toward GHG mitigation. Without baseline data from which prioritized actions can be made, local governments cannot properly engage the agriculture sector to take action or garner the public support that is important to do so.

\section{Identification of Key Policies: A number of policies} and regulations affecting agriculture and climate change were identified in table 1 . This does not include other policies that may influence agriculture production. A critical step toward implementing low GHG agriculture policies is to thoroughly evaluate all key policies and to identify levers, tools, synergies, impediments, conflicts, and contradictions between them. Additional review of the policy interface between agriculture, climate change, food security, trade, economics, and the environment is highly recommended. The goal would be to identify policies having the greatest influence over agriculture and to explore how agriculture GHG mitigation can support other policy goals (e.g., improving water and air quality, enhancing biodiversity, diversifying operations, enhancing local economics, and creating jobs).

\section{Stakeholder Participation in Improving Regulation: A} quagmire of policies and regulations exist that make it challenging to navigate climate action for agriculture. We recommend an open dialogue between those who create the regulations and those most directly affected by them in order to explore the question "how can regulations create opportunities to make the transition to low GHG agriculture possible?" In this way, the breadth of those concerned and affected can identify requisite policy adjustment and innovations.

\section{Local Governments Need Provincial Support for Innovative} Practices: Since local governments are required to establish GHG reduction targets in their planning documents, and must use their regulatory and approval authorities to achieve those targets, they can play a far-reaching role in climate action. However, they will lack resources and may need additional tools to properly influence GHG mitigation and adaptation within production agriculture. Therefore, it is essential that the province support innovative and transformational efforts made by their local governments. Programs like the Environmental Farm Plan enable producers to apply for economic incentives to implement beneficial management practices, many of which support climate change mitigation and adaptation (B.C. Ministry of Agriculture, 2011a). Similar programs implemented and promoted by local governments may assist production agriculture with implementing GHG mitigation actions.

\section{Conclusions}

Ultimately, anthropogenically induced climate change is a manifestation of how we, as individuals, live our lives and how our communities are organized and function. Planning for and implementing GHG mitigation in agriculture requires knowledge and consideration of a seemingly overwhelming number and complexity of features that directly and indirectly influence production agriculture. But, just because the situation is complex and hence very challenging, we cannot ignore the very real and substantial role agriculture plays in atmospheric GHG levels, and therefore its importance in GHG mitigation strategies.

\section{Acknowledgements}

We are grateful to Erik Karlsen, Arthur Fallick, Caitlin Dorward, and Theresa Dunystee for their technical advice and feedback.

\section{References}

Agriculture and Agri-food Canada (AAFC). (2010). The way forward: Summary of Agriculture and Agri-Food Canada's Science and Innovation Strategic Action Plan.

Retrieved from http://www4.agr.gc.ca/AAFCAAC/display-afficher.do?id=1271686453735 \&lang $=$ eng

Agricultural Land Commission (ALC). (2011). ALR \& Community Planning Guidelines. Retrieved from http://www.alc.gov.bc.ca/publications/ publications.htm\#Guide

Benfield, K. (2011, April 21). Agri-sprawl: "Farming is the new golf." Sustainable Cities Collective. Retrieved from http://sustainablecitiescollective.com/ kaidbenfield/8500/agri-sprawl-farming-new-golf 
British Columbia Healthy Communities. (2011). Climate change: Building shared leadership for climate action. Retrieved from http://www.bchealthycommunities.ca/content/ What $\% 20 \mathrm{We} \% 20 \mathrm{Do} /$ climatechange.asp

British Columbia Laws. (2011). Local Government Act: Part 25 Regional Growth Strategies. Retrieved from http://www.bclaws.ca/EPLibraries/bclaws new/ document/ID/freeside/96323 29

British Columbia Ministry of Community, Sport and Cultural Development. (2010). Community-wide climate action planning framework. Retrieved from http://www.toolkit.bc.ca/cw-actionplanning

B.C. Local Government Department. (2011). Official Community Plans. Retrieved April 5, 2011, from http://www.cscd.gov.bc.ca/lgd/planning/official community plans.htm

B.C. Ministry of Agriculture. (1998). Guide for bylaw development in farming areas. Retrieved from http://www.agf.gov.bc.ca/resmgmt/sf/guide to bylaw development/Guide to ByLaw Dev index. $\underline{\mathrm{htm}}$

B.C. Ministry of Agriculture. (2008a). The B.C. Agriculture Plan: Growing a healthy future for B.C. Families. Province of British Columbia. Retrieved April 9, 2011, from http://www.agf.gov.bc.ca/Agriculture Plan/

B.C. Ministry of Agriculture. (2008b). A crop for the 21st century: Carbon credits and agriculture in British Columbia. BC Ministry of Agriculture. Retrieved from http://www.al.gov.bc.ca/resmgmt/ClimateAction $\underline{\operatorname{Plan} /}$

B.C. Ministry of Agriculture. (2009, June). BC's agricultural sector and the Greenhouse Gas Reduction Targets Act. Retrieved from http://www.agf.gov.bc.ca/resmgmt/ClimateAction Plan/GGRTA.pdf

B.C. Ministry of Agriculture. (2011). Key legislation. Retrieved from http://www.agf.gov.bc.ca/ resmgmt/sf/keylegisl.htm

B.C. Ministry of Agriculture. (2011a). Environmental farm planning. Retrieved from http://www.agf.gov.bc.ca/ resmgmt/EnviroFarmPlanning/index.htm

B.C. Ministry of Agriculture. (2011b). Agricultural Area Plans. Retrieved from http://www.agf.gov.bc.ca/ resmgmt/sf/aap/index.htm

B.C. Ministry of Agriculture. (2011c). Completed Agriculture Area Plans, strategies \&o studies. Retrieved
April 9, 2011, from http://www.agf.gov.bc.ca/ resmgmt $/ \mathrm{sf} /$ aap $/$ strategies.htm

B.C. Ministry of Community and Rural Development. (2010). Climate Action Charter. Retrieved from http://www.env.gov.bc.ca/cas/mitigation/charter. $\underline{\mathrm{html}}$

B.C. Ministry of Community, Sport and Cultural Development. (2010). Community-wide climate action planning. Retrieved from http://www.toolkit.bc.ca/cw-actionplanning

B.C. Ministry of Environment. (2009). Climate action for the 21 st century. Retrieved from http://www.livesmartbc.ca/government/plan.html

B.C. Ministry of Environment, Climate Action Secretariat. (2009, June 30). Getting to carbon neutral government. LiveSmart BC. Retrieved from http://www.livesmartbc.ca/attachments/carbon neutral action reports/Getting to Carbon Neutral Government.pdf

City of Surrey. (2011). Sustainability charter. Retrieved April 18, 2011, from http://www.surrey.ca/plansstrategies/3152.aspx

City of Vancouver. (2011). Vancouver food charter.

Retrieved April 18, 2011, from http://vancouver.ca/commsvcs/socialplanning/ initiatives/foodpolicy/policy/charter.htm

Climate Action Initiative. (2010). BC Agriculture climate change action plan 2010-2013. Retrieved July 2, 2011, from http://www.bcagclimateaction.ca/wp/wpcontent/media/BC-Agriculture-Climate-ChangeAction-Plan.pdf

"Common Questions About $\mathrm{MtCO}_{2}$." (2008). MtCO2e - Metric Tonne Carbon Dioxide Equivalent. Retrieved Feb. 28, 2012, from http://www.mtco2e.com

Connell, D., \& Sturgeon, D. (2011). Evaluation of Agricultural Area Plans in British Columbia. University of Northern British Columbia. Retrieved from http://www.unbc.ca/planning/localfood/ evaluation of aaps.html

Curran, D. (2009). Capital Regional District agricultural legal \& policy scan. Prepared for the Capital Regional District Roundtable on the Environment, Food and Agriculture Subcommittee. Retrieved from the Capital Regional District website at http://www.crd.bc.ca/reports/planningtransporta ti /2009/06june/agendaitem5attachmen/ AgendaItem5-Attachment1b.pdf 
Department of Justice. (2011). Constitutional documents: Consolidation of constitution acts, 1867 to 1982. Retrieved April 4, 2011, from http://lawslois.justice.gc.ca/eng/Const/index.html

ecoAction. (2007). ecoAgriculture Biofuels Capital Initiative. Retrieved April 4, 2011, from http://www.ecoaction.gc.ca/ecoagriculture/ biofuels-biocarburants-eng.cfm

ecoAction. (2011). Canada's action on climate change. Retrieved April 4, 2011, from http://www.ecoaction.gc.ca/climatechangechangementsclimatiques/index-eng.cfm

Federation of Canadian Municipalities. (2011). Partners for climate protection. Retrieved July 2, 2011, from http://gmf.fcm.ca/Partners-for-ClimateProtection/

Federation of Canadian Municipalities \& Local Governments for Sustainability (ICLEI). (2010). Partners for Climate Protection: National measures report 2010. Retrieved July 2, 2011, from http://gmf.fcm.ca/files/Capacity_Building_PCP/PCP Resources/Measures Report 2010 English Final.pdf

Found, W. C. (1996). Agriculture in a world of subsidies. In J. N. H. Britton (Ed.), Canada and the global economy: The geography of structural and technological change (pp. 155-168). Montreal, Canada: McGillQueen's University Press.

Fuller, R. S., \& Buckingham, D. E. (1999). Agriculture law in Canada. Toronto, Canada: Butterworth.

Intergovernmental Panel on Climate Change (IPCC). (2007). Summary for Policymakers. In S. S. Solomon, D. Qin, M. Manning, Z. Chen, M. Marquis, K. B. Averyt, M. Tignor \& H. L. Miller (Eds.). Climate Change 2007: The Physical Science Basis (Contribution of Working Group I to the Fourth Assessment Report of the Intergovernmental Panel on Climate Change). Cambridge University Press, Cambridge, U.K., and New York, NY, USA. Retrieved from http://www.ipcc.ch/publications and_data/ar4/wg1/en/spm.html

Meridian Institute. (2011, June). Agriculture and climate change: A scoping report. Washington, D.C., USA: Author. Retrieved from http://www.climateagriculture.org/

Metro Vancouver. (2011). Regional food system strategy. Retrieved from http://www.metrovancouver.org/ planning/development/AgricultureAndFood/ Pages/RegionalFoodSystemStrategy.aspx
Moreau, T. L., Moore, J., \& Mullinix, K. (2011). Mitigating agriculture greenhouse gas emissions: A review of scientific information for food system planning. Journal of Agriculture, Food Systems, and Community Development. Advance online publication. http://dx.doi.org/10.5304/jafscd.2012.022.007

National Climate Change Secretariat. (1998). National climate change process: Municipalities issue table foundation paper. Ottawa, Canada: National Climate Change Process.

Natural Resources Canada. (2011). Preparing for climate change: Securing British Columbia's water future.

Retrieved April 9, 2011, from

http://www.adaptation.nrcan.gc.ca/collab/ bc e.php

Nowlan, L., Rolfe, C., \& Grant, K. (2001). The smart growth guide to local government law and advocacy. West Coast Environmental Law Research Foundation. Retrieved from the WCELRF website at http://wcel.org/resources/publication/smartgrowth-guide-local-government-law-and-advocacy

Scialabba, N., \& Muller-Lindenlauf, M. (2010). Organic agriculture and climate change. Renewable Agriculture and Food Systems, 25(2), 158-169. http://dx.doi.org/10.1017/S1742170510000116

Smith, B. (1998). Planning for agriculture. Retrieved from the Provincial Agricultural Land Commission website at http://www.alc.gov.bc.ca/publications/ planning/Planning for Agriculture/index.htm

Smith, P., Martino, D., Cai, Z., Gwary, D., Janzen, H., Kumar, P., ... Towprayoon, S. (2007). Policy and technological constraints to implementation of greenhouse gas mitigation options in agriculture. Agriculture, Ecosystems \& Environment, 118(1-4), 628. http://dx.doi.org/10.1016/j.agee.2006.06.006

Smith, P., Martino, D., Cai, Z., Gwary, D., Janzen, H., Kumar, P.,...Smith, J. (2008). Greenhouse gas mitigation in agriculture. Philosophical Transactions of the Royal Society B: Biological Sciences, 363(1492), 789813. http://dx.doi.org/10.1098/rstb.2007.2184

United Nations Framework Convention on Climate Change (UNFCCC). (2011). The United Nations Framework Convention on Climate Change. Retrieved from http://unfccc.int/essential background/ convention/items/2627.php 